\title{
Toxicity Studies of Sidha Medicine - Rasagandhi Mezhugu
}

\author{
Sheeja T. Tharakan ${ }^{1}$, Girija Kuttan ${ }^{1}$, Ramadasan Kuttan ${ }^{*}, 1$, M. Kesavan ${ }^{2}$, Sr. Austin ${ }^{2}$ and \\ K. Rajagopalan ${ }^{2}$ \\ ${ }^{I}$ Amala Cancer Research Centre, Amala Nagar, Thrissur 680 555, India \\ ${ }^{2}$ Amala Ayurvedic Hospital, Amala Nagar, Thrissur 680 555, India
}

\begin{abstract}
Sidha medicines which are popular in Southern parts of India have significant quantity of heavy metals. It is claimed that mode of preparation of these drugs reduces their toxicities. However toxicity studies of Sidha preparations are seldom carried out. In the present study we have evaluated toxicity of Rasagandhi Mezhugu (RM), a Sidha preparation in Wistar rats. Drug was administered orally as single dose (acute) and sixty doses (chronic). Parameters checked were WBC count, haemoglobin and differential count, hepatic function tests such as SGOT, SGPT, ALP, bilirubin, creatinine, blood urea nitrogen, total protein, albumin, globulin and renal function tests such as blood urea nitrogen and creatinine, electrolytes such as sodium, potassium, bicarbonate and chloride. No impairment in hepatic, renal, haemopoietic functions were observed throughout the study. Histopathological analysis revealed that liver, kidney, spleen and thymus tissues of treated groups did not show any signs of toxicity. However, astrocytes showed mild hyperplasia, stroma showed oedema in the treated group. Cerebellum also shows stromal oedema. Rasagandhi Mezhugu (RM) administration for one year to HIV patients did not produce any toxicity as seen from liver function and renal function as well as analyzing haematological parameters. Analysis of the metal content in the tissues of RGM treated rats for one month indicated that there was significant accumulation of mercury and copper in the tissues, which indicate that RGM administration for long period of times can produce heavy metal toxicity which is also indicated in histopathological analysis.
\end{abstract}

Keywords: Mercury, rasagandhi mezhugu, sulphur, siddha medicine, toxicity.

\section{INTRODUCTION}

Sidha medicine is being practiced in Southern part of India. Most medical practitioners caution against using Sidha medicines due to the extensive use of heavy metals like lead and mercury in the preparation. Drugs having these heavy metals more than their allowable limits are banned in many countries. Sidha practitioners claim that the heavy metals used in these medicines are completely transformed into inert compounds or ores through a 18-step process before being prescribed as medicine. However extensive research is necessary to solve such riddles of the transformation of these admittedly poisonous compounds. Recently Sidha system of medicare has been found to have useful in the management of HIV through scientific research involving viral load assays and $\mathrm{CD} 4^{+} / \mathrm{CD} 8^{+}$ratios [1].

Rasagandhi Mezhugu (RGM) in the form of a capsule is being used for the treatment of HIV by some practitioners [2]. This preparation contain 38 different botanicals, many of which have been shown to possess therapeutic efficacy, and 8 inorganic compounds such as mercury, sulphur, calomel (mercury chloride), yellow orpiment (arsenic sulphide), lodestone (iron), blue vitriol (copper sulfate), calamine (zinc oxide) and litharge (lead oxide), all prepared into a paste in palm sugar and hen's egg base. Composition of RGM is given elsewhere [3].

*Address correspondence to this author at the Amala Cancer Research Centre, Amala Nagar, Thrissur, Kerala, 680 555, India; Tel: +91487 2304190; Fax: +91487 2307968; E-mail: amalacancerresearch@gmail.com
The question of toxicity in this preparation has still not been properly addressed. In the present study we have checked the safety of RGM, in animals and human beings.

\section{MATERIALS AND METHODS}

\subsection{Animals}

Male Wistar rats were purchased from Small Animal Breeding Station, Veterinary College, Thrissur. Animals were housed in ventilated cages and were given mouse chow (Sai Durga Foods and Feeds, Bangalore) and water ad libitum. All animal experiments were conducted after getting sanction from Institutional Animal Ethics Committee and as per the instructions prescribed by the Committee for the Purpose of Conduct and Supervisions of Experiments on Animals (CPCSEA), Ministry of Environment and Forest, Government of India. Treatment of HIV patients were done at Amala Ayurvedic Hospital, Amala Nagar, Thrissur. All chemicals used in these experiments were of analytical reagent grade and purchased locally.

\subsection{Rasagandhi Mezhugu}

RGM was purchased from the Indian Medical Practitioners, Co-operative Pharmacy \& Stores Ltd., Thiruvanniyur, Chennai. Each capsule contained $300 \mathrm{mg}$ of RGM. HPTLC pattern (HPTLC plates silica gel 60F 254) using Butanol-Acetic acid glacyl-water 4:1:1 of RGM is given in Fig. (1). 


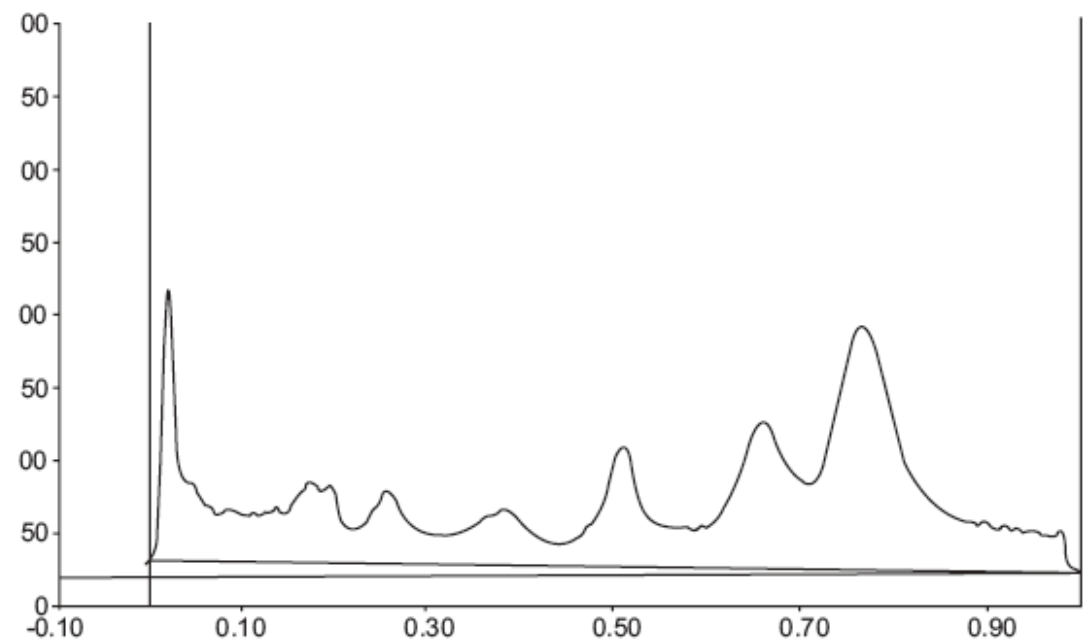

Fig. (1). HPTLC profile of Rasagandhi mezhugu (RGM).

\subsection{Acute and Chronic Toxicity of RGM in Rats}

In order to study acute and chronic toxicity of RGM, rats were randomly divided into following groups (6animals/ group). Group I was kept normal. In acute toxicity studies, single dose of RGM 1.5 and $0.75 \mathrm{~g} / \mathrm{kg}$ body weight were orally administered by a cannula and rats were observed for 14 days. In chronic toxicity studies animals were treated with 60 doses 0.75 and $0.325 \mathrm{~g} / \mathrm{kg}$ body weight RGM. This dose is equal to 150 times greater than human dose. Mortality of animals and any adverse reactions such as diarrhoea, weight loss, immobility and any other visual changes in the behaviour were observed. Food consumption and body weight were measured every third day in acute and every week in chronic toxicity studies. For this food particles were removed from the cage and a known quantity of the feed was added in the cage. After 24h, remaining feed was collected and weighed.

In acute toxicity studies, animals were sacrificed on the $15^{\text {th }}$ day while in chronic studies they were sacrificed on the $60^{\text {th }}$ day. The shape, size and colours of internal organs were visually observed during necropsy for any signs of lesions. Blood was collected by heart puncture method. It was collected into heparinized or non-heparinized tubes for haematological and biochemical analyses.

Following haematological parameters were checked (a) total WBC count (haemocytometer method) [4]; (b) haemoglobin (cyanomethaemoglobin method) [5]; (c) analysis of blood cells. Serum was separated from animals treated with these drugs and biochemical analysis of serum samples was performed using prepared kits from Roche Diagnostic reagents. Methods used were serum glutamate oxaloacetate transaminase (SGOT) (International Federation of Clinical Chemistry (IFCC) Method) [6], serum glutamate pyruvate transaminase (SGPT) (IFCC method), alkaline phosphatase (ALP) (IFCC method), bilirubin total and direct (Jen Drasik and Grof method), creatinine (Jaffe and Kinetic method), blood urea nitrogen (Glyceraldehyde dehydrogenase method) [7], total protein (Biuret method), albumin (Bromo Cresol Green method) and globulin. These assays were performed with the aid of a Hitachi-902 automated biochemistry analyzer. Serum sodium and potassium were estimated using Biolyte 2000 (Version 3. 2) ion elective electrolyte analyzer.
Bicarbonate was determined by total $\mathrm{CO}_{2}$ detection by Randox Phosphoenol pyruvate carboxylase-malate dehydrogenase method [8]. Chloride is estimated calorimetrically using the kit of Raichem, Mumbai.

Histopathological analysis of the liver, kidney, intestine, brain, spleen and thymus were performed by cutting $2 \mathrm{~mm}$ sections of the tissue fixed in $10 \%$ formaldehyde by a microtome and further staining with haematoxylin and eosin and were examined by a pathologist.

\subsection{Heavy Metal Content of RGM in Various Tissues by Atomic Absorption Spectroscopy}

Metal content of RGM in tissues was done by atomic absorption spectroscopy (PerkinElmer) at Department of Animal Nutrition, Veterinary College, Mannuthy. For this, sample was weighed into $50 \mathrm{ml}$ quartz crucible and mixed with $50 \%$ magnesium nitrate hexahydrate solution $(0.8 \mathrm{ml}$ to $1 \mathrm{~g}$ sample). It was dried, cooled. $1 \mathrm{ml}$ of concentrated nitric acid was added and put ash on a hot plate to get dry. The ash must be carbon free. $1 \mathrm{~g}$ sample ash was dissolved in $1 \mathrm{ml}$ 4.5 $\mathrm{N}$ hydrochloric acid. Each analysis was read against a reagent blank [9].

\subsection{Toxicity Profile of RGM in HIV Patients}

Amala Ayurvedic centre has been treating HIV patients with herbal formulations NCV I (10g/day) and AC II (10g/day) along with RGM (2 capsule/day) for the last several years. In the present study blood from 25 patients were analyzed before and after treatment with these formulations for 1 year for possible hepatic, renal and haematological toxicity of these preparations. Parameters are the same as given above for animal toxicity analysis.

\section{RESULTS}

\subsection{Acute Toxicity}

\subsubsection{Effect of RGM on Haematological and Biochemical Parameters}

There was no significant changes of total WBC count; haemoglobin content in animals treated with RGM (Table 1). 
Table 1. Effect of Acute Administration of RGM in Rats

\begin{tabular}{|c|c|c|c|}
\hline \multirow{2}{*}{ Parameters } & \multirow{2}{*}{ Normal } & \multicolumn{2}{|c|}{ RGM } \\
\hline & & $1.5 \mathrm{~g} / \mathrm{kg} \mathrm{b.wt}$ & $0.75 \mathrm{~g} / \mathrm{kg} \mathrm{b.wt}$ \\
\hline Total WBC count $\times 10^{3} \mathrm{~mm}^{3}$ & $7992 \pm 372$ & $7917 \pm 231$ & $77767 \pm 361$ \\
\hline Bilirubin total $(\mathrm{mg} / \mathrm{dl})$ & $0.05 \pm 0.03$ & $0.08 \pm 0.02$ & $0.15 \pm 0.25$ \\
\hline Bilirubin direct (mg/dl) & $0.01 \pm 0.005$ & $0.03 \pm 0.26$ & 0.02 \\
\hline $\operatorname{ALP}(\mathrm{U} / \mathrm{L})$ & $195.25 \pm 26$ & $318.31 \pm 88^{* * *}$ & $259.8 \pm 33.5$ \\
\hline Albumin (mg/dl) & $3.85 \pm 0.36$ & $3.95 \pm 0.3$ & $3.98 \pm 0.35$ \\
\hline Globulin (mg/dl) & $2.7 \pm 0.35$ & $2.97 \pm 0.36$ & $3.7 \pm 0.4^{* *}$ \\
\hline Total protein & $6.55 \pm 0.24$ & $6.91 \pm 0.36$ & $6.68 \pm 0.56$ \\
\hline Chloride $(\mathrm{mEq} / \mathrm{L})$ & $78.5 \pm 14.41$ & $86.66 \pm 22.4$ & $80.7 \pm 21.1$ \\
\hline Bicarbonate (mEq/L) & $15.41 \pm 2.24$ & $27.55 \pm 3.74$ & $38.66 \pm 23.8^{* * *}$ \\
\hline
\end{tabular}

There was no significant change of haemoglobin content and differential counts (data not shown). SGPT level was altered significantly $(p<0.01)$ in higher concentrations of RGM capsules. However values were within the normal limits of rats at low concentration. No significant change was noticed in SGOT level. The ALP values were significantly increased in higher concentration of RGM capsule. However these values are within the normal range of rats. The level of urea was altered in RGM $(0.75 \mathrm{~g} / \mathrm{kg}$ body weight $)$ but the values are within the normal range. There was no significant change in the creatinine in treated groups. Acute administration of these capsules did not produce any alteration in sodium, potassium and chloride levels. Serum bicarbonate electrolyte level was altered in $\mathrm{RGM} 0.75 \mathrm{~g} / \mathrm{kg}$ body weight treated groups, but this level was within the normal range.

\subsection{Chronic Toxicity}

\subsubsection{Effect of RGM on Mortality, Body Weight and Food Consumption}

Chronic administration of RGM did not produce any mortality or adverse reactions in rats during acute and chronic studies. There was no significant change in the body weight of the animals treated with RGM capsule (Fig. 2).

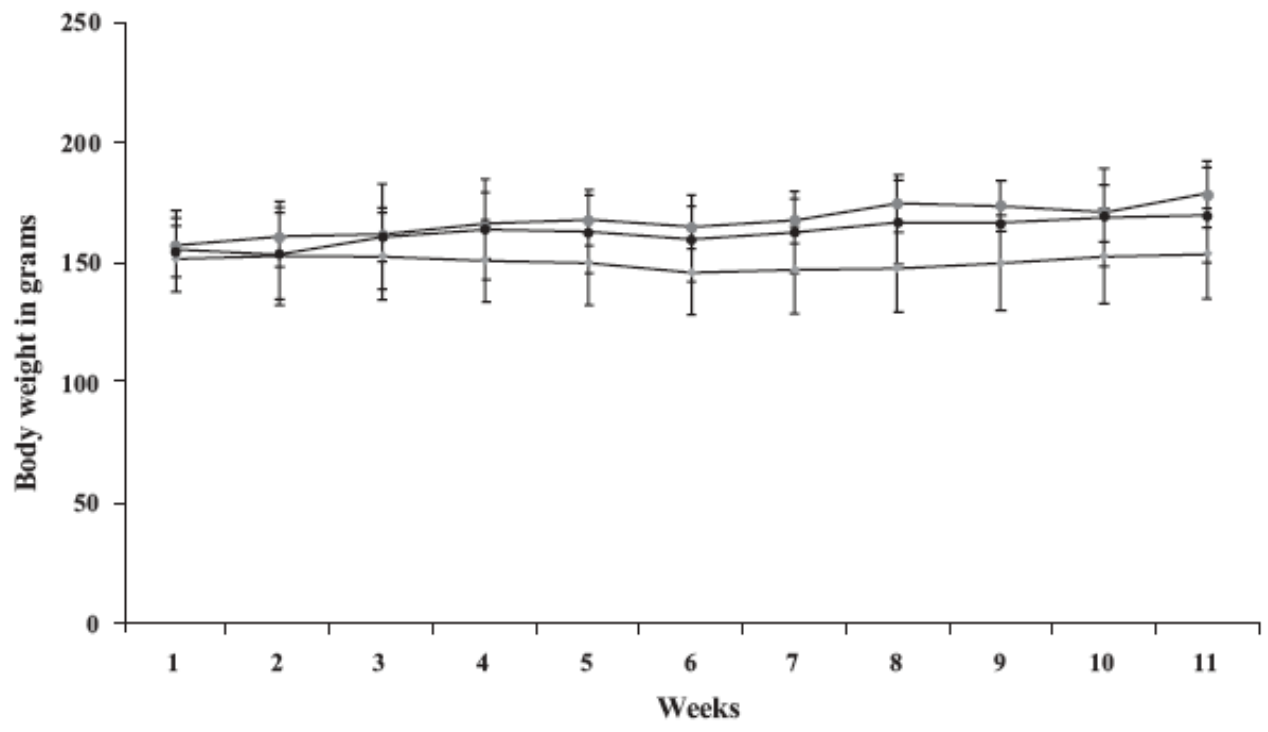

Fig. (2). Effect of chronic administration of Rasagandhi mezhugu (RGM) on body weight.

$-\bullet \quad$ Normal

- Rasagandhi mezhugu $0.75 \mathrm{~g} / \mathrm{Kg}$ body weight

Rasagandhi mezhugu $0.325 \mathrm{~g} / \mathrm{Kg}$ body weight 


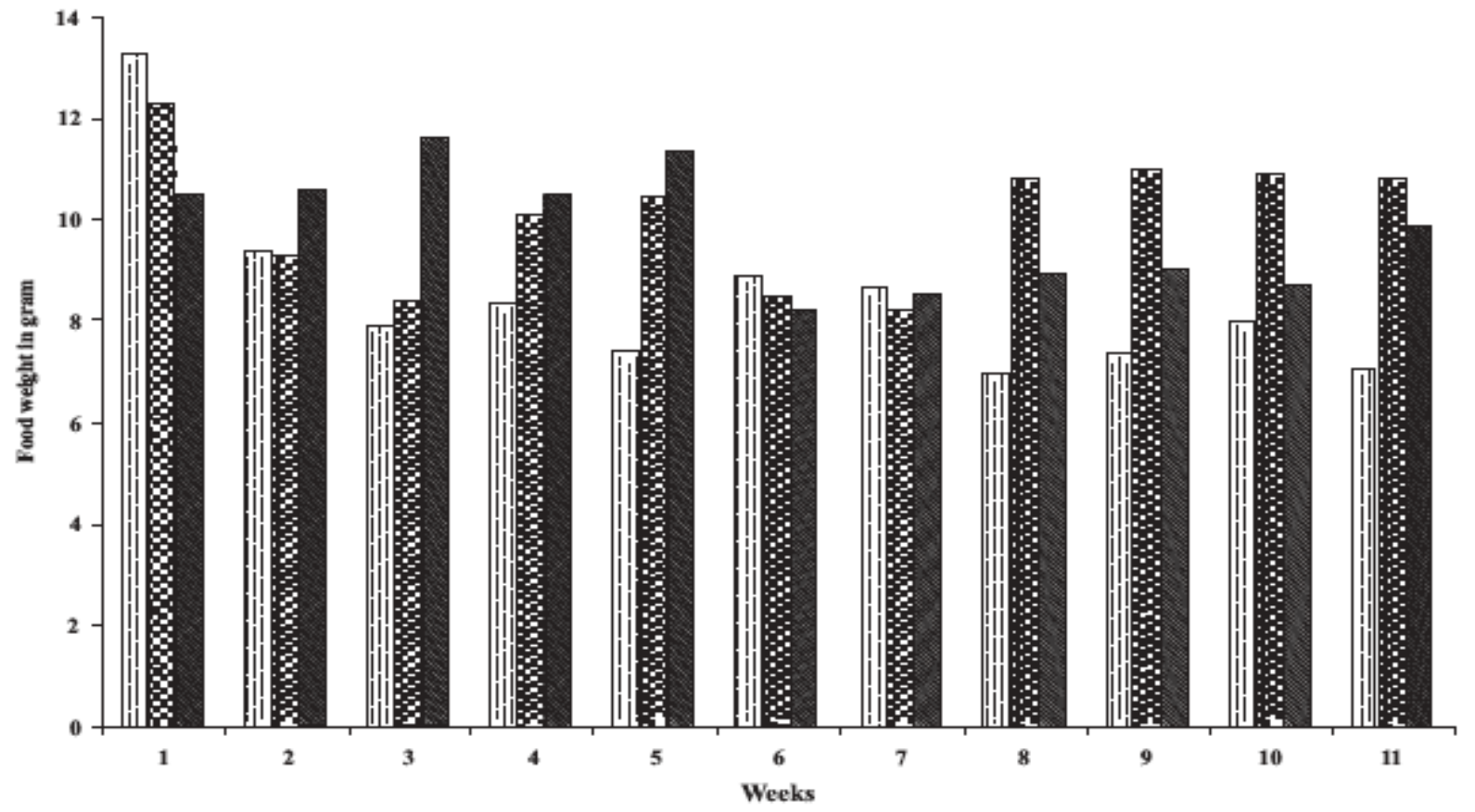

Fig. (3). Effect of chronic administration of Rasagandhi mezhugu (RGM) on food consumption.

Normal

Rasagandhi mezhugu $0.75 \mathrm{~g} / \mathrm{Kg}$ body weight

Rasagandhi mezhugu $0.325 \mathrm{~g} / \mathrm{Kg}$ body weight

There was no significant difference in the food consumption of rats treated with different doses of this capsule (Fig. 3).

\subsubsection{Effect of RGM on Haematological and Biochemical Parameters}

Chronic administration increased the total WBC count significantly when compared with the normal groups. There was no significant change of haemoglobin content and differential counts. There was no significant alteration in hepatic and renal function parameters. Chronic administration of these drugs did not produce any alteration in sodium, potassium, chloride and bicarbonate levels (Table 2).

No remarkable histopathological changes were noted in the internal organs of rats receiving these drugs (Figs. 4, 5).

Table 2. Effect of Chronic Administration of RGM in Rats

\begin{tabular}{|c|c|c|c|}
\hline \multirow{2}{*}{ Parameters } & \multirow{2}{*}{ Normal } & \multicolumn{2}{|c|}{ RGM } \\
\hline & & $0.75 \mathrm{~g} / \mathrm{kg} \mathrm{b.wt}$ & $0.325 \mathrm{~g} / \mathrm{kg} \mathrm{b.wt}$ \\
\hline Total WBC count $\times 10^{3} \mathrm{~mm}^{3}$ & $6392 \pm 498$ & $8083 \pm 422^{* * *}$ & $7633 \pm 225^{* *}$ \\
\hline Haemoglobin $(\mathrm{mg} / \mathrm{dl})$ & $11.98 \pm 2.85$ & $10.15 \pm 2.34$ & $12.35 \pm 1.0$ \\
\hline Bilirubin total $(\mathrm{mg} / \mathrm{dl})$ & $0.3 \pm 0.15$ & $0.42 \pm 0.29$ & $0.32 \pm 0.22$ \\
\hline Bilirubin direct $(\mathrm{mg} / \mathrm{dl})$ & $0.26 \pm 0.36$ & $0.42 \pm 0.29$ & $0.11 \pm 0.05$ \\
\hline SGPT (U/L) & $72.8 \pm 10.5$ & $88.8 \pm 14.1$ & $74.83 \pm 13.38$ \\
\hline SGOT (U/L) & $176.4 \pm 31.6$ & $176.3 \pm 17.26$ & $143.2 \pm 17.65$ \\
\hline $\operatorname{ALP}(\mathrm{U} / \mathrm{L})$ & $419.8 \pm 94.1$ & $493.8 \pm 142.5$ & $467.7 \pm 154.3$ \\
\hline $\operatorname{Albumin}(\mathrm{mg} / \mathrm{dl})$ & $3.63 \pm 0.42$ & $3.42 \pm 0.56$ & $3.62 \pm 0.52$ \\
\hline Globulin (mg/dl) & $4.03 \pm 0.19$ & $4.03 \pm 0.36$ & $4.00 \pm 0.39$ \\
\hline Total protein & $7.66 \pm 0.28$ & $7.45 \pm 0.42$ & $7.62 \pm 0.52$ \\
\hline BUN (mg/dl) & $66.58 \pm 7.45$ & $56.13 \pm 6.6$ & $63.26 \pm 7.48$ \\
\hline Creatinine (mg/dl) & $0.46 \pm 0.05$ & $0.38 \pm 0.04$ & $0.38 \pm 0.04$ \\
\hline Sodium $(\mathrm{mEq} / \mathrm{L})$ & $148 \pm 3.43$ & $148.8 \pm 2.92$ & $150.3 \pm 7.6$ \\
\hline Potassium $(\mathrm{mEq} / \mathrm{L})$ & $5.15 \pm 0.38$ & $5.2 \pm 0.49$ & $4.9 \pm 0.53$ \\
\hline Chloride $(\mathrm{mEq} / \mathrm{L})$ & $101 \pm 3.28$ & $105 \pm 2.28$ & $102.8 \pm 5.07$ \\
\hline Bicarbonate $(\mathrm{mEq} / \mathrm{L})$ & $31.0 \pm 3.68$ & $34.6 \pm 2.5$ & $32.3 \pm 3.88$ \\
\hline
\end{tabular}

\footnotetext{
$* * \mathrm{p}<0.01$ Values are average of six animals.
} 


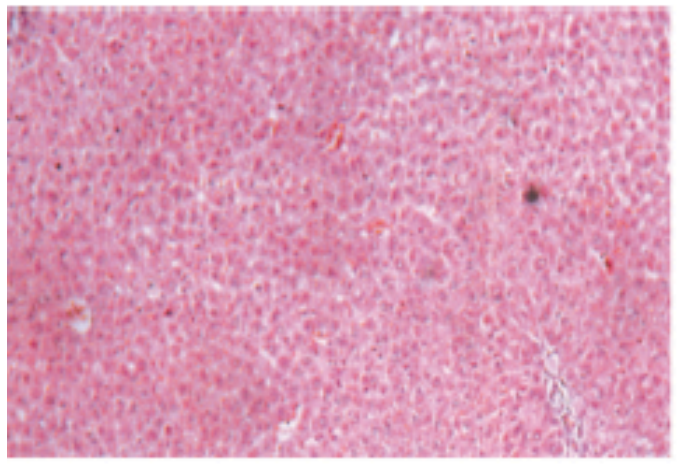

(a)

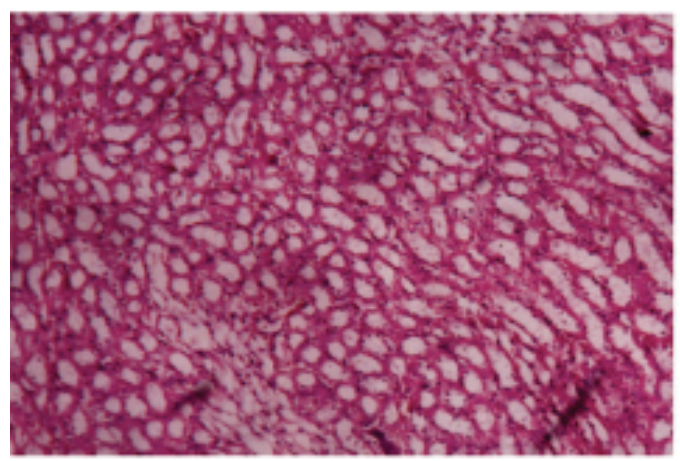

(c)

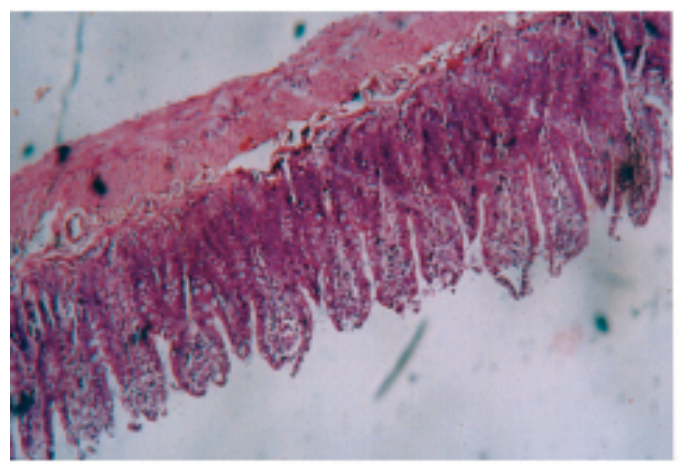

(e)

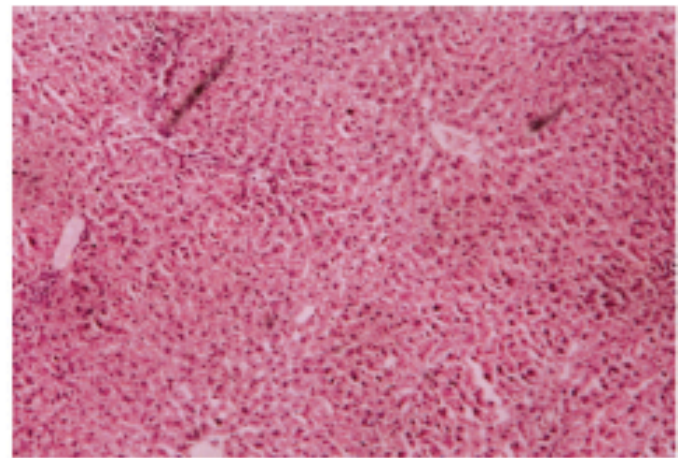

(b)

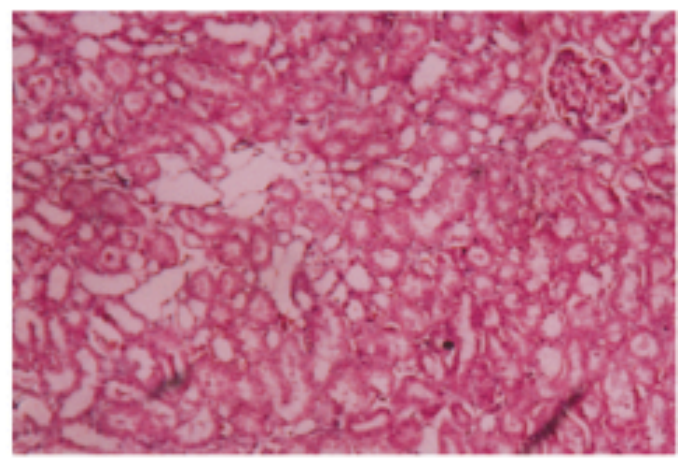

(d)

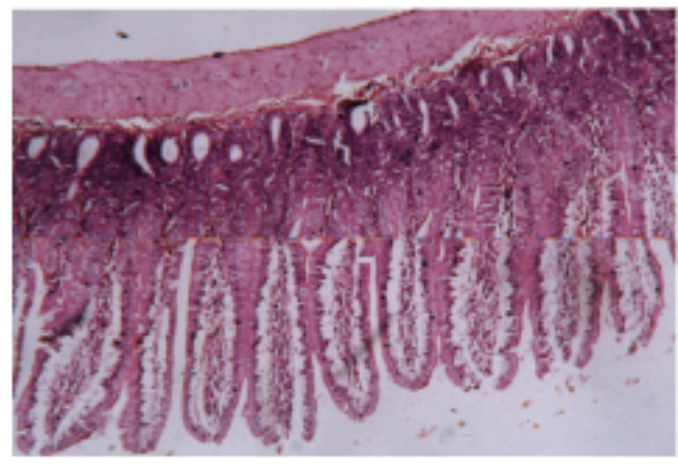

(f)

Fig. (4). Histopathology of liver, kidney and intestine after chronic administration of Rasagandhi mezhugu (RGM).

a) Normal liver, b) Treated liver (Rasagandhi mezhugu $0.75 \mathrm{~g} / \mathrm{Kg}$ body weight)

c) Normal kidney, d) Treated kidney (Rasagandhi mezhugu $0.75 \mathrm{~g} / \mathrm{Kg}$ body weight)

e) Normal intestine, f) Treated intestine (Rasagandhi mezhugu $0.75 \mathrm{~g} / \mathrm{Kg}$ body weight)

Liver tissues showed normal structure. Portal area and central venous system appeared normal. Hepatocytes showed normal morphology. Kupffer cells and sinusoidal spaces were normal.

Kidney showed normal glomeruli. Renal tubes were normal. Interstitial tissues also appeared mild oedema. No other specific lesion seen. Intestine showed normal villi and mucosal glands. Mucosa, submucosa and muscularis mucosa did not show any specific pathological lesion.
In normal group, section of brain shows normal glial cells. Astrocytes appear normal. Stroma shows mild oedema. Portion of cerebellum is seen which appears normal. In treated group, astrocytes showed mild hyperplasia. Stroma showed oedema. Cerebellum also shows stromal oedema.

Section of spleen showed lymphoid follides with germinal centres. Sinusoidal spaces were dilated and congested. There was lymphstasis and areas of haemorrhage. In treated 


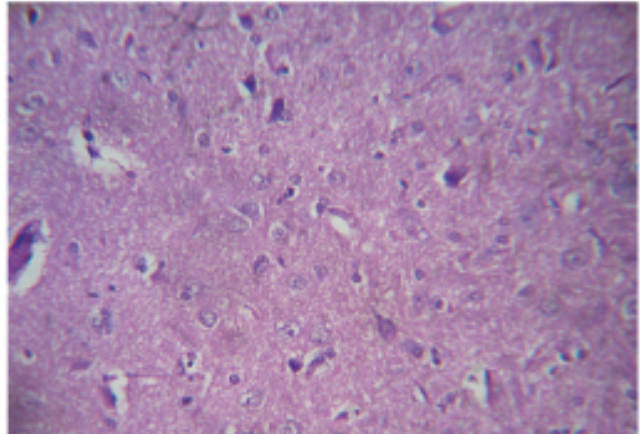

(a)

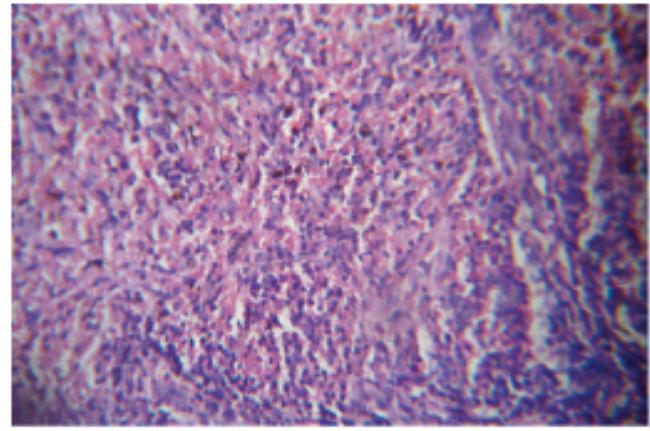

(c)

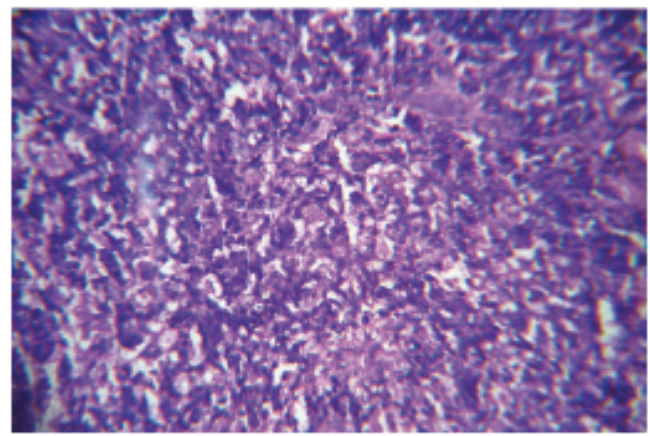

(e)

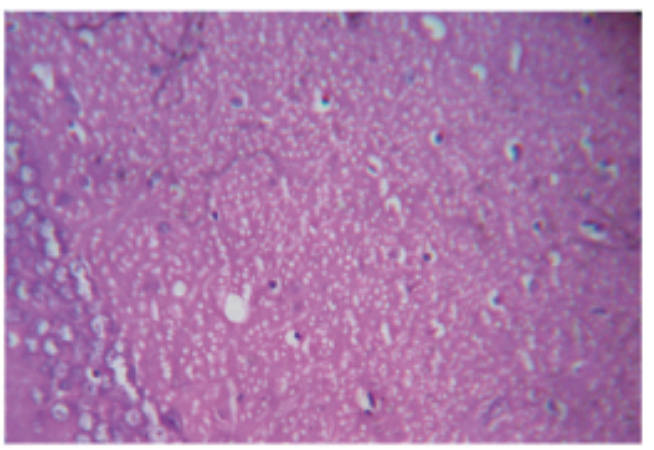

(b)

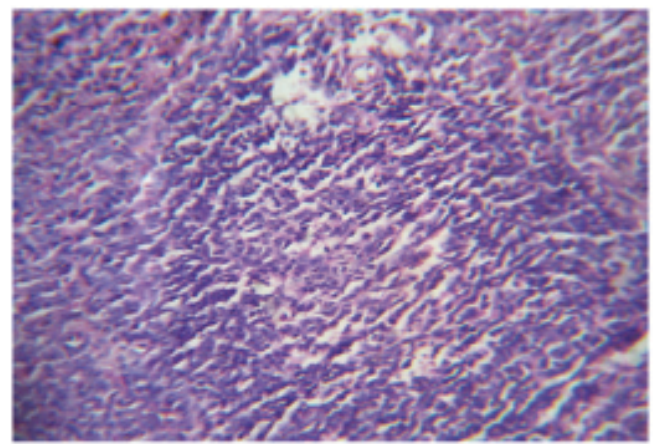

(d)

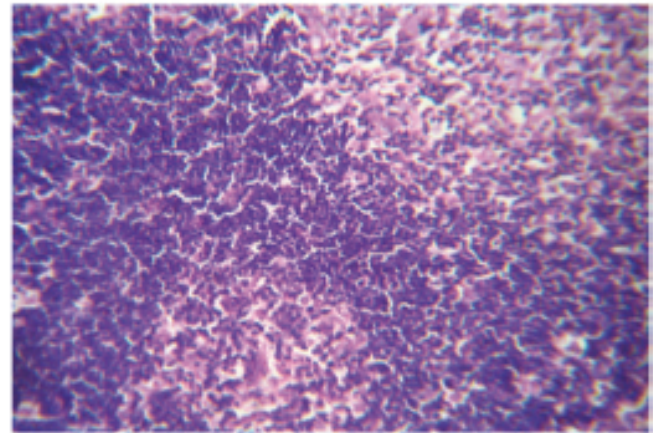

(f)

Fig. (5). Histopathology of brain, spleen and thymus after chronic administration of Rasagandhi mezhugu (RGM).

a) Normal brain, b) Treated brain (Rasagandhi mezhugu $0.75 \mathrm{~g} / \mathrm{Kg}$ body weight)

c) Normal spleen, d) Treated spleen (Rasagandhi mezhugu $0.75 \mathrm{~g} / \mathrm{Kg}$ body weight)

e) Normal thymus, f) Treated thymus (Rasagandhi mezhugu $0.75 \mathrm{~g} / \mathrm{Kg}$ body weight)

group, no pathological lesions were found in spleen and section was similar to normal.

In normal and treated group, section of thymus showed normal structure. There are sheets of lymphocytes and groups of thymic epithelial cells. Normal Hassal bodies are seen.

\subsection{Heavy Metal Content of RGM in Various Tissues}

Atomic absorption spectroscopy analysis of various tissues was shown in Table 3. Absorption of copper, mercury, lead and arsenic was analyzed in liver, kidney, brain, blood and urine by AAS and the average concentration of each element was expressed in this table. Levels of lead and arsenic were found to be higher in treated groups, but they are not significant. The level of mercury was found to be significantly high in all tissues, blood and urine of treated group. The level of copper was also found to be higher in liver and kidney of treated group while in brain, blood and urine values were found to be similar to normal.

\subsection{Effect of RGM in HIV Patients}

Administration of the medication including RGM increased body weight of HIV patients in most of the cases. Out of 25 patients studied, the body weight was increased in 21 
Table 3. Heavy Metal Content of RGM in Various Tissues

\begin{tabular}{|c|c|c|c|c|}
\hline Tissues & Copper & Mercury & Lead & Arsenic \\
\hline $\begin{array}{l}\text { Normal liver } \\
\text { Treated liver }\end{array}$ & $\begin{array}{c}0.14 \pm 0.53 \\
7.87 \pm 1.8 * * *\end{array}$ & $\begin{array}{c}\text { Nil } \\
44.2 \pm 19.14 * *\end{array}$ & $\begin{array}{c}4.4 \pm 7.6 \\
8.1 \pm 8.89\end{array}$ & $\begin{array}{c}77.06 \pm 21.14 \\
124.06 \pm 138.1\end{array}$ \\
\hline $\begin{array}{l}\text { Normal kidney } \\
\text { Treated kidney }\end{array}$ & $\begin{array}{c}8.4 \pm 1.9 \\
36.2 \pm 11.15^{* *}\end{array}$ & $\begin{array}{c}4.2 \pm 7.3 \\
151 \pm 38^{* * *}\end{array}$ & $\begin{array}{l}5.6 \pm 5.7 \\
10 \pm 2.9\end{array}$ & $\begin{array}{c}426.2 \pm 117 \\
636.8 \pm 289.7\end{array}$ \\
\hline $\begin{array}{l}\text { Normal brain } \\
\text { Treated brain }\end{array}$ & $\begin{array}{c}8.4 \pm 3.38 \\
7.2 \pm 3.6\end{array}$ & $\begin{array}{c}56.2 \pm 44.97 \\
169.9 \pm 110.67 * * *\end{array}$ & $\begin{array}{l}15.6 \pm 7.7 \\
10.6 \pm 5.5\end{array}$ & $\begin{array}{l}832.4 \pm 133 \\
978.9 \pm 449\end{array}$ \\
\hline $\begin{array}{l}\text { Normal blood } \\
\text { Treated blood }\end{array}$ & $\begin{array}{c} \pm 0.5 \\
1.21 \pm 0.3\end{array}$ & $\begin{array}{c}\text { Nil } \\
58.5 \pm 46.23 * *\end{array}$ & $\begin{array}{l}1.3 \pm 0.8 \\
2.2 \pm 1.5\end{array}$ & $\begin{array}{c}467.3 \pm 26.81 \\
458.3 \pm 110.04\end{array}$ \\
\hline $\begin{array}{l}\text { Normal urine } \\
\text { Treated urine }\end{array}$ & $\begin{array}{c}1.1 \\
0.95\end{array}$ & $\begin{array}{c}\text { Nil } \\
11\end{array}$ & $\begin{array}{l}2.1 \\
2.4\end{array}$ & $\begin{array}{l}477 \\
315\end{array}$ \\
\hline
\end{tabular}

Values are expressed as ppm tissue of ash.

patients (range 1 to $10 \mathrm{Kg}$; average $3 \mathrm{Kg}$ ) after one year. In four patients body weight did not show any change. Analysis of haematological, hepatic and renal parameters in the patients is shown in Table 4. After one-year treatment, RBC,

Table 4. Effect of Administration of RGM in HIV Patients for 1 Year

\begin{tabular}{|c|c|c|}
\hline Clinical Parameters & Pretreatment & 1-Year Post Treatment \\
\hline \hline Body weight & $48.0 \pm 8.6$ & $51.52 \pm 9.2$ \\
\hline RBC count $\times 10^{6} / \mu 1$ & $4.08 \pm 0.41$ & $3.48 \pm 0.76$ \\
\hline Haematocrit $(\%)$ & $32.35 \pm 3.57$ & $31.95 \pm 6.63$ \\
\hline Haemoglobin $(\mathrm{mg} / \mathrm{dl})$ & $11.93 \pm 4.75$ & $11.3 \pm 5.52$ \\
\hline Platelet count $\times 10^{3} / \mu 1$ & $167.91 \pm 58.31$ & $151.91 \pm 51.5$ \\
\hline WBC count $\times 10^{3} / \mu 1$ & $6.98 \pm 1.55$ & $5.86 \pm 1.42$ \\
\hline SGOT $(\mathrm{U} / \mathrm{L})$ & $20.54 \pm 7.25$ & $21.91 \pm 13.06$ \\
\hline SGPT $(\mathrm{U} / \mathrm{L})$ & $8.00 \pm 3.01$ & $16.14 \pm 11.71 * *$ \\
\hline ALP $(\mathrm{U} / \mathrm{L})$ & $58.35 \pm 16.55$ & $50.22 \pm 29.0$ \\
\hline Urea $(\mathrm{mg} / \mathrm{dl})$ & $17.89 \pm 5.0$ & $22.84 \pm 5.95 * *$ \\
\hline Creatinine $(\mathrm{mg} / \mathrm{dl})$ & $0.71 \pm 0.14$ & $0.71 \pm 0.12$ \\
\hline Globulin $(\mathrm{mg} / \mathrm{dl})$ & $4.03 \pm 0.19$ & $4.03 \pm 0.36$ \\
\hline Total $\mathrm{protein}$ & $7.66 \pm 0.28$ & $7.45 \pm 0.42$ \\
\hline Sodium $(\mathrm{mEq} / \mathrm{L})$ & $139.95 \pm 7.20$ & $141.27 \pm 5.11$ \\
\hline Potassium $(\mathrm{mEq} / \mathrm{L})$ & $4.75 \pm 0.86$ & $4.32 \pm 0.53$ \\
\hline$* * \mathrm{p}<0.01$. These values are average of 25 patients. & \\
\hline
\end{tabular}

WBC, haematocrit, haemoglobin and platelet count values did not show any significant change in all the patients studied. Marker enzymes of hepatic function such as serum glutamate oxaloacetate transaminase did not show any significant change after treatment with this medication. Average values of serum glutamate pyruvate transaminase showed significant increase after the medication treatment, which may be due to the increased values of SGPT in two sick patients. SGPT values in other patients were found to be unaltered after treatment. Another liver function marker, alkaline phosphatase did not show any change. Renal function markers like urea and creatinine did not show significant change except in two patients. The electrolyte levels were unaltered in all the patients during the course of treatment. These results indicate that the administration of the drug did not produce any haematological and organ toxicity in patients.

Blood samples were collected for hematological estimations before and after treatment with the medication. WBC, $\mathrm{RBC}, \mathrm{Hb}$, platelet count and hematocrit were determined using a haematology analyzer. SGOT, SGPT, ALP, Urea and Creatinine were determined with commercially available kits using a Hitachi 704 fully automated analyzer. The levels of electrolytes were estimated using a Biolyte 2000 counter.

\section{DISCUSSION}

Heavy metal contamination, adulteration with modern pharmaceuticals and prohibited animal and plant ingredients are regularly reported in some herbal remedies [10]. Rasagandhi mezhugu (RGM), a Sidha preparation is being practiced by Sidha practitioners for several diseases including acquired immunodeficiency with good success [2, 3, 11]. RGM as well as other Sidha medicines contained several heavy metals as their active ingredients. Insufficient data exist for most herbal drugs including Sidha preparations to guarantee their quality, efficacy and safety.

Acute toxicity study indicated that $1.5 \mathrm{~g} / \mathrm{kg}$ body weight RGM given orally to rats did not induce death, suggesting the safety of the preparation. This concentration is 150 times higher than the therapeutic dose. Similarly during chronic studies 75 times higher than the therapeutic dose for 60 days did not produce any significant organ or haematologic toxicity in animals.

The macroscopic analysis of internal organs of the treated animals did not show any significant change in colour and texture when compared with the normal group. All parameters obtained from the blood and serum was in 
normal range indicating RGM did not show any noticeable toxic changes.

Histopathological analysis revealed that liver, kidney, spleen and thymus tissues of treated groups did not show any signs of toxicity. Pathological analysis of brain in treated groups, showed mild hyperplasia in astrocytes and oedema in stroma and cerebellum.

Analysis of the rat tissues of heavy metal content indicated that the administration of RGM produced significant increase in the level of mercury in liver, kidney, brain as well as in the urine. Similarly copper content was very high in liver and kidney of treated rats. The levels of lead and arsenic did not show significance compared to normal. Sidha practitioners claim that many of their preparations containing heavy metals do not produce any toxicity to internal organs. However, the accumulation of mercury and copper in the rat tissues may indicate that long term intake of Sidha preparations can produce toxic symptoms in the patients. Interestingly administration of RGM even after one year in HIV patients did not alter the haematological and serum parameters and these patients did not show any signs of toxicity.

Curcumin pretreatment has shown a protective effect against intoxication of mercury [12]. An observable regression on the severity such as hemorrhage, hepatocyte degeneration and tubular degeneration of kidney was observed in mercury-treated mice supplemented with different doses of lycopene [13]. This observation also indicated that Sidha preparations containing several herbals may have reduced toxic potential.

Usefulness of Sidha medicines in many ailments including HIV has been shown proved beyond doubt. However mechanism of action of these drugs is not understood properly. Since the Sidha preparations always use high heat to produce bhasmas (ash) [14]. It is possible that the ingredients present in these preparations can be very much different from the original drugs. Absorption and distribution of these drugs have not been clearly understood. In the present study, indicate that even though RGM does not produce any immediate toxicity, its role in inducing long term toxicity cannot be overruled.

\section{REFERENCES}

[1] Paradela A, Rivas C, Fernandez- Guerrero M, Roman A. Histopathology of bone marrow biopsy in patients with human immunodeficiency virus infection. Rev Clin Esp 1996; 196: 9-15.

[2] Deivanayagam CN. Siddha medicines are effective in controlling HIV/AIDS - a report. Proc. National Seminar on the use of traditional medicines in HIV infection and AIDS, Thrissur, Kerala, India 2002.

[3] Ranga RS, Girija R, Nur-e-Alam M, et al. Rasagenthi lehyam (RL) a novel complementary and alternative medicine for prostate cancer. Cancer Chemother Pharmacol 2004; 54: 7-15.

[4] Cheesbrough M, Arthur MM. A laboratory manual for rural tropical hospitals, Churchill Livingstone, London 1976.

[5] Drabkin DL, Austin JM. Spectrophotometric studies, Spectrophotometric constants for common haemoglobin derivatives in human, dog and rabbit blood. J Biol Chem 1932; 98: 719-33.

[6] Glick MR, Ryder KW, Jackson SA. Graphical comparisons of interferences in clinical chemistry instrumentations. Clin Chem 1986; 32: 470-74.

[7] Passing H, Bablok WA. New biochemical procedure for testing the quality of measurements from two analytical methods. J Clin Biochem 1983; 81: 709-20.

[8] Muller-Plathe O. Acid base balance and blood gases. In: Thomas L, Ed. Clinical laboratory diagnostics. Frankfurt: TH-Books Verlagsgesell-schaft, 1998; pp. 318-29.

[9] Szkoda J, Zmudzki J, Grzebalska A. Determination of arsenic in biological material by hydride generation atomic absorption spectrometry method. Bull Vet Inst Pulawy 2006; 50: 269-72.

[10] Corns CM. Herbal remedies and clinical biochemistry. Ann Clin Biochem 2003; 40: 489-507.

[11] Ranga RS, Girija R, Sowmyalakshmi S, Burikhanov R, Akbarsha MA, Chendil D. A herbal medicine for the treatment of lung cancer. Mol Cell Biochem 2005, 280: 125-33.

[12] Agarwal R, Goel SK, Behari JR. Detoxification and antioxidant effects of curcumin in rats experimentally exposed to mercury. J Appl Toxicol 2010; [Epub ahead of print].

[13] Cavusoglu K, Oruc E, Yapar K, Yalcin E. Protective effect of lycopene against mercury-induced cytotoxicity in albino mice: pathological evaluation. J Environ Biol 2009; 30: 807-14.

[14] Kumar A, Nair AG, Reddy AV, Garg AN. Bhasmas: unique ayurvedic metallic- herbal preparations, chemical characterization. Biol Trace Elem Res 2006; 109: 231-54.

This is an open access article licensed under the terms of the Creative Commons Attribution Non-Commercial License (http://creativecommons.org/licenses/by$\mathrm{nc} / 3.0 /$ ), which permits unrestricted, non-commercial use, distribution and reproduction in any medium, provided the work is properly cited. 